\title{
Prediction of fecal indicator organism concentrations in rivers: the shifting role of environmental factors under varying flow conditions
}

\author{
Ilona Herrig ${ }^{1,2^{*}}$, Wolfgang Seis ${ }^{3,4}$, Helmut Fischer ${ }^{5}$, Julia Regnery' ${ }^{1}$, Werner Manz ${ }^{2}$, Georg Reifferscheid
} and Simone Böer ${ }^{1,6}$

\begin{abstract}
Background: Fecal indicator organisms such as Escherichia coli, enterococci, and coliphages are important to assess, monitor, and predict microbial water quality in natural freshwater ecosystems. To improve predictive modelling of fecal indicators in surface waters, it is vital to assess the influence of autochthonous and allochthonous environmental factors on microbial water quality in riverine systems. To better understand how environmental conditions influence the fate of fecal indicators under varying weather conditions, the interdependencies of environmental parameters and concentrations of E. coli, intestinal enterococci, and somatic coliphages were studied at two rivers (Rhine and Moselle in Rhineland-Palatinate, Germany) over a period of 2 years that exhibited contrasting hydrological conditions. Both riverine sampling sites were subject to similar meteorological conditions based on spatial proximity, but differed in hydrodynamics and hydrochemistry, thus providing further insight into the role of river-specific determinants on fecal indicator concentrations. Furthermore, a Bayesian multiple linear regression approach that complies with the European Bathing Water Directive was applied to both rivers' datasets to test model transferability and the validity of microbial water quality predictions in riverine systems under varying flow regimes.
\end{abstract}

Results: According to multivariate statistical analyses, rainfall events and high water discharge favored the input and dissemination of fecal indicators in both rivers. As expected, concentrations declined with rising global solar irradiance, water temperature, and $\mathrm{pH}$. While variations in coliphage concentrations were predominantly driven by hydro-meteorological factors, bacterial indicator concentrations were strongly influenced by autochthonous biotic factors related to primary production. This was more pronounced under low flow conditions accompanied by strong phytoplankton blooms. Strong seasonal variations pointed towards bacterial indicator losses due to grazing activities. The Bayesian linear regression approach provided appropriate water quality predictions at the Rhine sampling site based on discharge, global solar irradiance, and rainfall as fecal indicator distributions were predominantly driven by hydro-meteorological factors.

Conclusions: Assessment of microbial water quality predictions implied that rivers characterized by strong hydrodynamics qualify for multiple linear regression models using readily measurable hydro-meteorological parameters. In rivers where trophic interactions exceed hydrodynamic influences, such as the Moselle, viral indicators may pose a more reliable response variable in statistical models.

\footnotetext{
*Correspondence: iherrig@uni-koblenz.de

${ }^{2}$ Department of Biology, Institute for Integrated Natural Sciences,

University of Koblenz-Landau, 56070 Koblenz, Germany

Full list of author information is available at the end of the article
}

Springer Open

(c) The Author(s) 2019. This article is distributed under the terms of the Creative Commons Attribution 4.0 International License (http://creativecommons.org/licenses/by/4.0/), which permits unrestricted use, distribution, and reproduction in any medium, provided you give appropriate credit to the original author(s) and the source, provide a link to the Creative Commons license, and indicate if changes were made. 
Keywords: Bathing water quality, E. coli, European Bathing Water Directive, Intestinal enterococci, Somatic coliphages, Trophic interactions, Water hygiene assessment

\section{Introduction}

Besides their main anthropogenic functions as waterways, drinking water resources, and irrigation systems, rivers are widely used for a variety of recreational activities, including water sports such as swimming, water skiing, or canoeing. If microbial water quality is poor, human exposure to river water due to unintended ingestion during swimming or inhaling of spray can pose severe health threats. Among others, the health risks most closely associated with bathing are fecal-orally transmitted gastrointestinal diseases [1]. Not only participants in water-contact sports are at high risk, also activities involving partial water contact such as boating and fishing carry an increased risk of gastrointestinal illnesses compared to other non-aquatic recreational activities [2].

Rivers can undergo rapid changes in microbial water quality driven by a wide range of factors including hydrological, biological, hydrogeochemical, and meteorological conditions. In particular, parameters such as water discharge, conductivity, $\mathrm{pH}$, water temperature, dissolved oxygen $\left(\mathrm{O}_{2}\right)$, rainfall, turbidity, and global solar irradiance are related to fecal indicator organism (FIO) concentrations in aquatic environments (e.g., [3-6]).

The European Bathing Water Directive (EBWD) (76/160/EEC 2006) states that the maximum of the 90th percentiles of the bacterial fecal indicators must not exceed $900 \mathrm{MPN} / 100 \mathrm{~mL}$ of E. coli and $330 \mathrm{CFU} / 100 \mathrm{~mL}$ of intestinal enterococci, respectively, based on the bathing seasons of four consecutive years [7]. Maximum permissible values for viral fecal indicators are not included in the EBWD. However, somatic coliphages had been suggested as potential indicators for viral contamination [8]. For bathing waters known to be impaired by shortterm pollution (e.g., caused by combined sewer overflows or agricultural run-off during rainfall events), reliable early warning systems are demanded by the EBWD to reduce the risk of exposure. One major drawback is that the demands of the EBWD do not provide reliable shortterm bathing water quality assessments.

To overcome these challenges, statistical model approaches based on readily measurable environmental variables are frequently proposed as promising early warning systems for impairments of recreational water quality (e.g., [9-11]). Yet, the lack of a single sample threshold and the limited information provided by periodic samples complicate the implementation of reliable models in compliance with the EBWD [12, 13]. In addition, mechanistic models are commonly used for long-term assessments of management practices or the understanding of underlying dynamics $[14,15]$. Although several recently published models are capable of predicting $E$. coli contamination levels in water bodies, more work is required to improve their accuracy and reliability, especially with regard to pathogen fate and transport [15-17]. In particular, identification and selection of model input parameters are critical aspects when implementing models for pathogen transport in water bodies. Modelling success is often limited by insufficient data sets or lacking knowledge of processes and parameters affecting microorganism behavior in water bodies $[15$, 17].

Recently, an innovative assessment approach was developed which translates the probabilistic character of the EBWD to short-term (daily) water quality assessments [13]. The approach interprets the existing bathing water threshold as a linear regression model with no predictors and extends the model by readily available hydrological variables. Moreover, the approach is not solely restricted to these kinds of variables, but encourages the user to apply any reasonable and available data to build the model. The approach's validity was demonstrated at a riverine bathing site in Berlin, Germany, and transferability to other riverine bathing sites was suggested [13]. Nevertheless, models as well as data availability are often site specific, which may hamper large-scale application $[15,18]$ and thus complicate their transferability to other sites. Further on, more frequently observed extreme or atypical meteorological and hydrological conditions at riverine sites might alter the influence of readily measurable environmental variables on FIO concentrations and diminish the predictive capabilities of existing models.

To study the influence of autochthonous and allochthonous environmental factors on microbiological water pollution in riverine systems during highly contrasting flow regimes, relevant environmental parameters and FIO concentrations of $E$. coli, intestinal enterococci, and somatic coliphages were monitored over the course of 1 year each in 2010/2011 and 2016/2017 at two sites at the Rhine River and its tributary the Moselle River (Germany). Both sampling sites were located in the city of Koblenz, Germany, near the confluence of both rivers.

The aims of this study were

1. to determine riverine FIO dynamics dependence on specific environmental factors under contrasting flow regimes in distinct riverine habitats, 
2. to assess seasonal patterns of individual riverine FIO concentrations,

3. to study the effect of different river types and flow conditions on the assessment approach proposed by Seis et al. [13], and

4. to evaluate the effects of site-specific processes on model transferability and performance.

Results of this study will help to improve future modelling approaches of pathogen occurrences in surface waters and enhance the capability to develop strategies to reduce human exposure risks during aquatic recreational activities. Moreover, results may allow conclusions on the validity of microbial water quality predictions in riverine systems under varying flow regimes.

\section{Results}

\section{River characteristics and seasonality of environmental} parameters

The flow regime of both rivers differed considerably (Fig. 1). Throughout sampling campaigns 1 and 2, the average discharge was $1502 \mathrm{~m}^{3} / \mathrm{s}$ and $1701 \mathrm{~m}^{3} / \mathrm{s}$ in the Rhine and $256 \mathrm{~m}^{3} / \mathrm{s}$ and $320 \mathrm{~m}^{3} / \mathrm{s}$ in the Moselle, respectively (Table 1). The first sampling campaign was characterized by remarkably low discharges during the months of March, May, and November 2011, whereas substantially higher water levels were observed throughout sampling campaign 2. Several flood events occurred during springtime and early summer months in 2016 (Fig. 1).

Conductivity levels in Moselle were twice as high as those observed in the Rhine (Table 1, Additional file 1: Figure S1), mostly owing to sodium carbonate production in upstream sections of the catchment [19]. Overall, conductivity exhibited a distinct negative correlation with discharge in both rivers (Rhine: $r=-0.77$, Moselle: $r=-0.65, p<0.05)$, but showed much more variation in the Moselle (Table 1; Additional file 1: Figure S1A).

At both sampling sites, average chlorophyll $a$ concentrations determined during campaign 1 (max. Rhine: $62.5 \mu \mathrm{g} / \mathrm{L}$, max. Moselle: $93.5 \mu \mathrm{g} / \mathrm{L}$ ) exceeded those in campaign $2(\max$. Rhine: $26.6 \mu \mathrm{g} / \mathrm{L}$, max. Moselle: $10.4 \mu \mathrm{g} / \mathrm{L}$ ). On average, chlorophyll $a$ concentrations in the Rhine were approximately 33\% lower than in the Moselle (Table 1, Fig. 2). In both rivers, average $\mathrm{pH}$ values and $\mathrm{O}_{2}$ concentrations ranged between 7.9 and 8.1, and $9.8 \mathrm{mg} / \mathrm{L}$ and $10.8 \mathrm{mg} / \mathrm{L}$, respectively. Increased $\mathrm{O}_{2}$ concentrations were observed in the Moselle during phytoplankton blooms. In addition, enhanced phytoplankton production resulted in markedly higher $\mathrm{pH}$ values due to the binding of dissolved carbon dioxide from the aqueous phase (Fig. 2).

In sampling campaign 1 , chlorophyll $a$ levels were positively correlated with $\mathrm{pH}$ in both rivers (Rhine: $r=0.61$, $p<0.05, n=48$, Moselle: $r=0.66, p<0.05, n=51)$ and with $\mathrm{O}_{2}$ concentration in the Moselle $(r=0.52, p<0.05$, $n=51$ ). This indicates a strong relation between $\mathrm{pH}, \mathrm{O}_{2}$ content, and primary production, which was particularly pronounced under low-flow conditions.

Summer, fall, and winter samples from both sampling campaigns tended to cluster together in the PCA plots of the major hydrochemical and meteorological characteristics, while spring samples clustered separately (Fig. 3). $74.9 \%$ of the variance in the Rhine data was explained by selected environmental parameters (Fig. 3a). On the contrary, the selected major environmental parameters explained only $65.8 \%$ of the variance in the Moselle data set (Fig. 3b). Samples collected in summer were positively associated with global solar irradiance and ambient water temperature. At both sites and campaigns, winter samples were positively associated with $\mathrm{O}_{2}$ and to a lesser extent also with hydrology-related parameters. Spring samples, however, showed substantial differences among sampling campaigns. Variations in samples from campaign 2 can be explained by hydro-meteorological parameters (i.e., discharge, rainfall, and turbidity), whereas those of campaign 1 were dominated by elevated $\mathrm{pH}$ values (Fig. 3).

\section{Fecal indicator concentrations and seasonal patterns}

The FIO E. coli, intestinal enterococci, and somatic coliphages were detected in all river water samples (Table 1). However, five samples of $E$. coli were below the method quantitation limit (one each during both campaigns at the Moselle; three during the second campaign at the Rhine). Overall, highest concentrations of FIO were measured during high-flow events, while low FIO concentrations generally coincided with times of low water discharge and high global solar irradiance (Fig. 1). Except for somatic coliphages in the Moselle during the second sampling campaign (1004 PFU/100 mL), E. coli were the most abundant FIO on average in both rivers (Rhine: $811 \mathrm{MPN} / 100 \mathrm{~mL}$ in 2010/11 and $941 \mathrm{MPN} / 100 \mathrm{~mL}$ in 2016/17; Moselle: $928 \mathrm{MPN} / 100 \mathrm{~mL}$ in 2010/11 and 782 MPN/100 mL in 2016/17).

PCA of indicator data revealed distinct seasonal patterns in FIO concentrations across both years (Additional file 1: Figure S2). Overall, considerable overlap was observed among clusters. This was less pronounced for samples collected during the first sampling campaign, where spring and winter samples clustered separately. During times of increasing $\mathrm{pH}$ values in spring (Fig. 3), decreased FIO concentrations were observed (Additional file 1: Figure S2). The major part of variance (Rhine 43.1\%; Moselle: 37.9\%) is explained by principal component (PC) 1 in all cases. PC 2 explains $13.8 \%$ to $22.1 \%$ of variance in Moselle, but less than $10 \%$ in Rhine. 


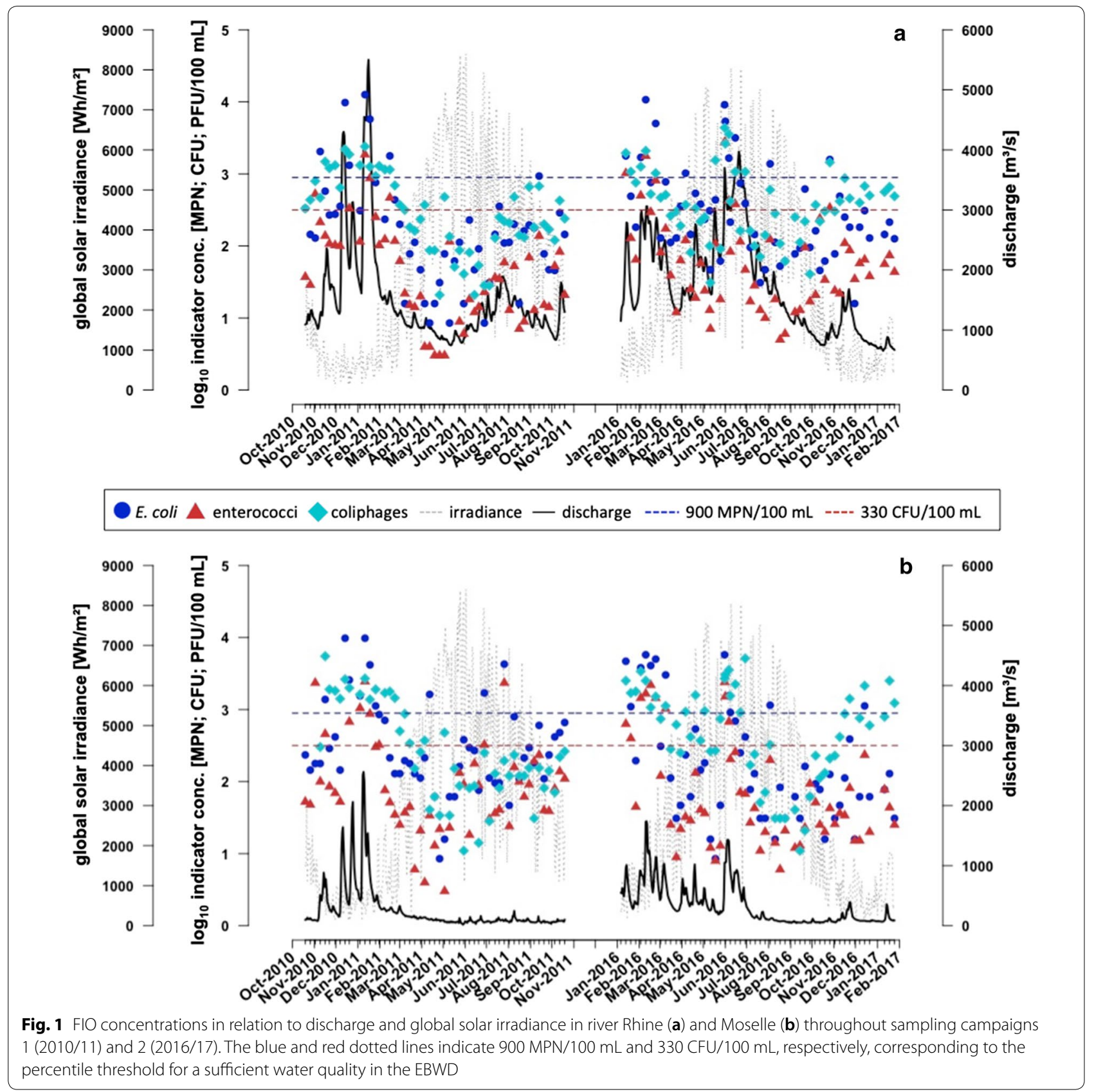

The least proportion of explained variance was observed in Moselle during low-flow regime in 2010/2011 (Additional file 1: Figure S2C).

In general, correlation analysis indicated a positive correlation between all FIO. Correlations in the Rhine were of comparable strength (i.e., $r=0.75$ to 0.79 , $p<0.05, n=103)$. Yet, weakest correlations occurred between $E$. coli and coliphages and strongest correlations between enterococci and coliphages. In Moselle, correlations between the bacterial and viral indicators ( $r=0.52$ to $0.56, p<0.05, n=96$ ) were considerably less pronounced than correlations among the bacterial indicators themselves ( $r=0.85, p<0.05, n=96)$.

Calculated ratios of enterococci:E. coli, E. coli:phages, and enterococci:phages indicated differences in the fate of bacterial indicators in both rivers depending on year (Additional file 1: Figure S3). Bacterial FIO abundances experienced a higher variability than coliphages. Notably, coliphage concentrations remained high during 


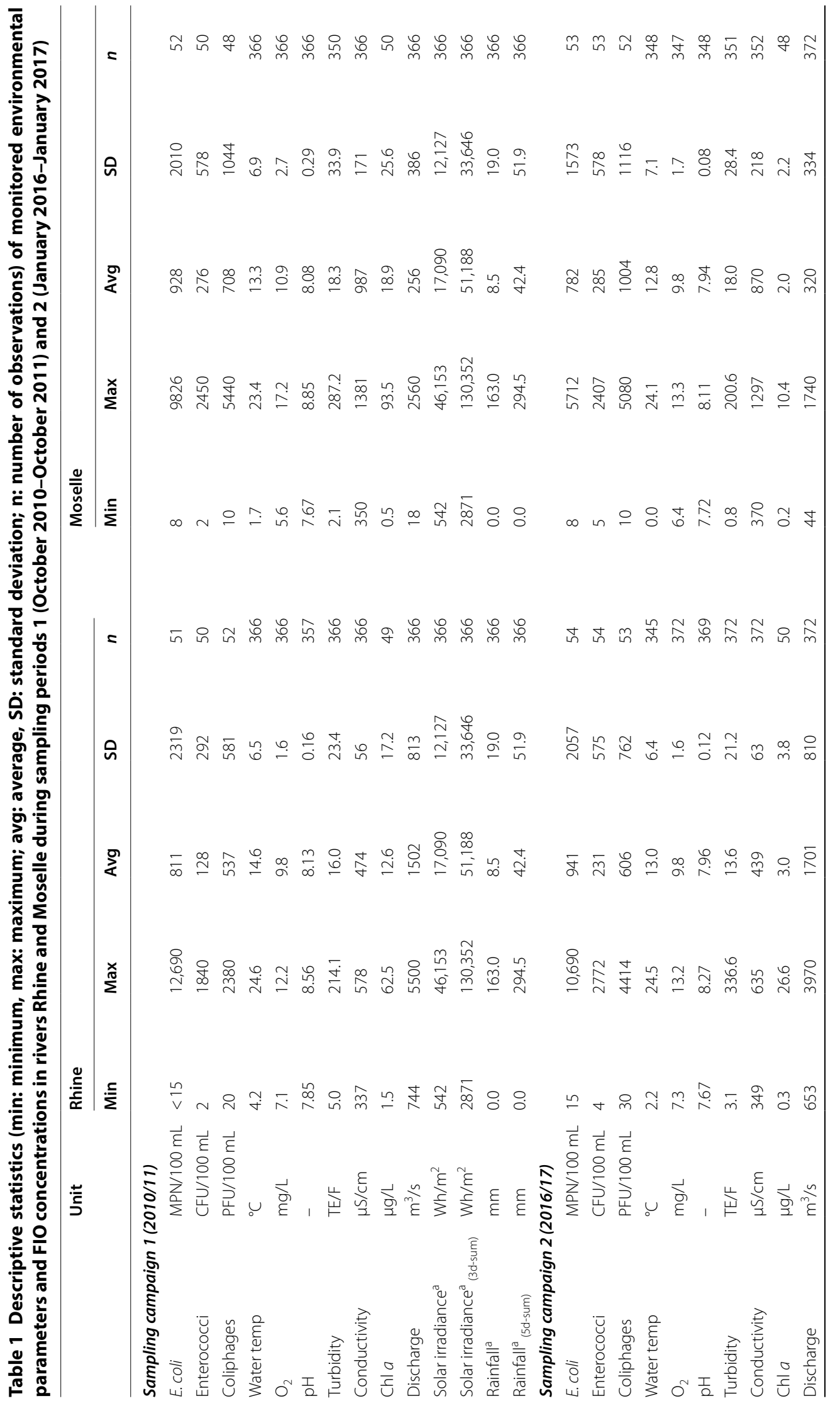




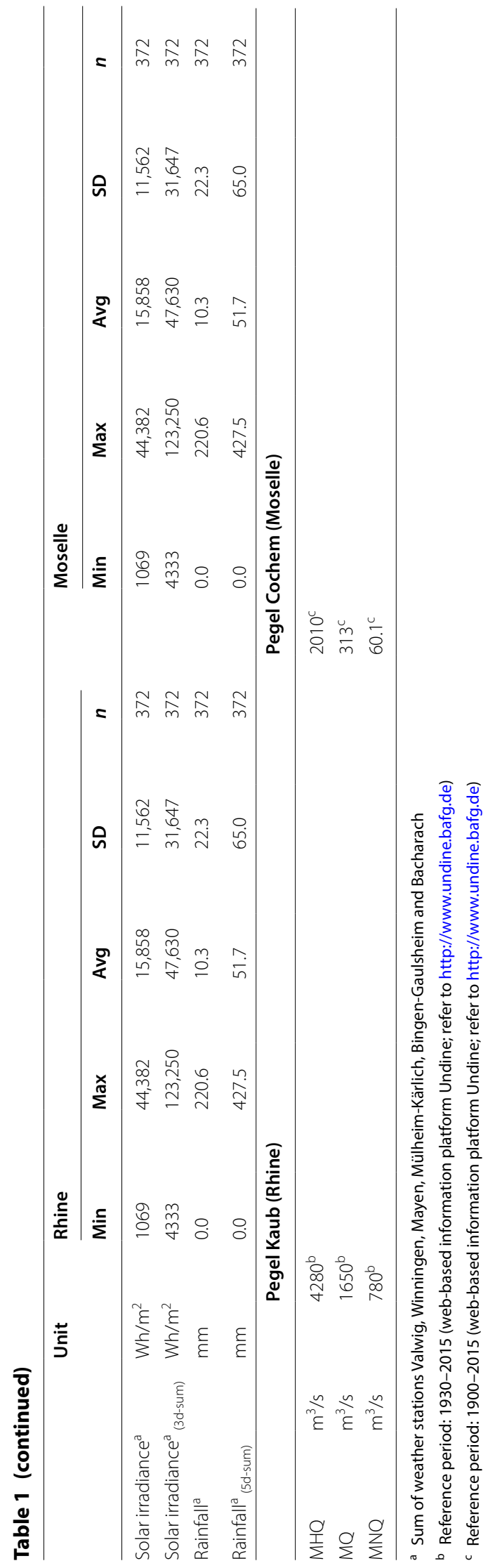



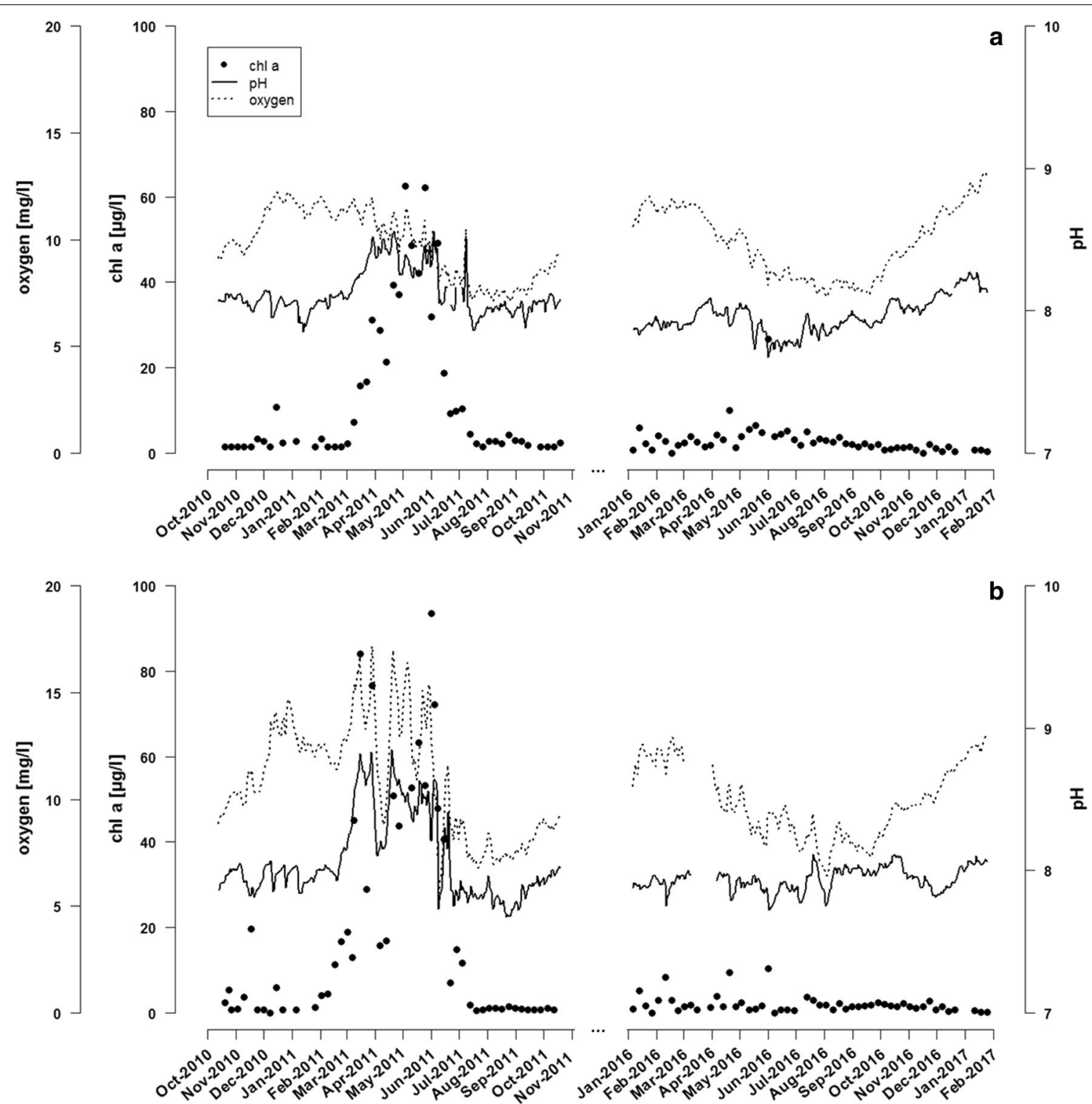

Fig. 2 Changes in chlorophyll a content, $\mathrm{pH}$ and oxygen concentrations in river Rhine (a) and river Moselle (b) throughout sampling campaigns 1 (2010/11) and $2(2016 / 17)$

winter months irrespective of discharge. This was not observed for bacterial FIO (Additional file 1: Figure S4).

\section{Fecal indicator dependence on environmental factors}

All measured environmental parameters correlated with at least one FIO during Spearman's rank correlation analyses and can thus be considered as potentially relevant for the fate and transport of FIO in both rivers (Table 2). Negative correlations were established between FIO and water temperature, $\mathrm{pH}$, conductivity, and global solar irradiance, while rainfall, $\mathrm{O}_{2}$, turbidity, and discharge were positively correlated with FIO concentrations. More specific, somatic coliphages showed stronger correlations with water temperature, global solar irradiance, and $\mathrm{O}_{2}$ irrespective of sampling location compared to bacterial FIO. While conductivity played a minor role in Rhine, especially somatic coliphages were negatively correlated with conductivity at the Moselle site (Table 2).

Redundancy analysis (RDA) revealed differences in relations between FIO and multiple environmental variables during years of hydrologically different conditions (Fig. 4). Global solar irradiance, rainfall, and turbidity were found to be explaining parameters in all cases except Moselle under low-flow conditions in 2010/11. 

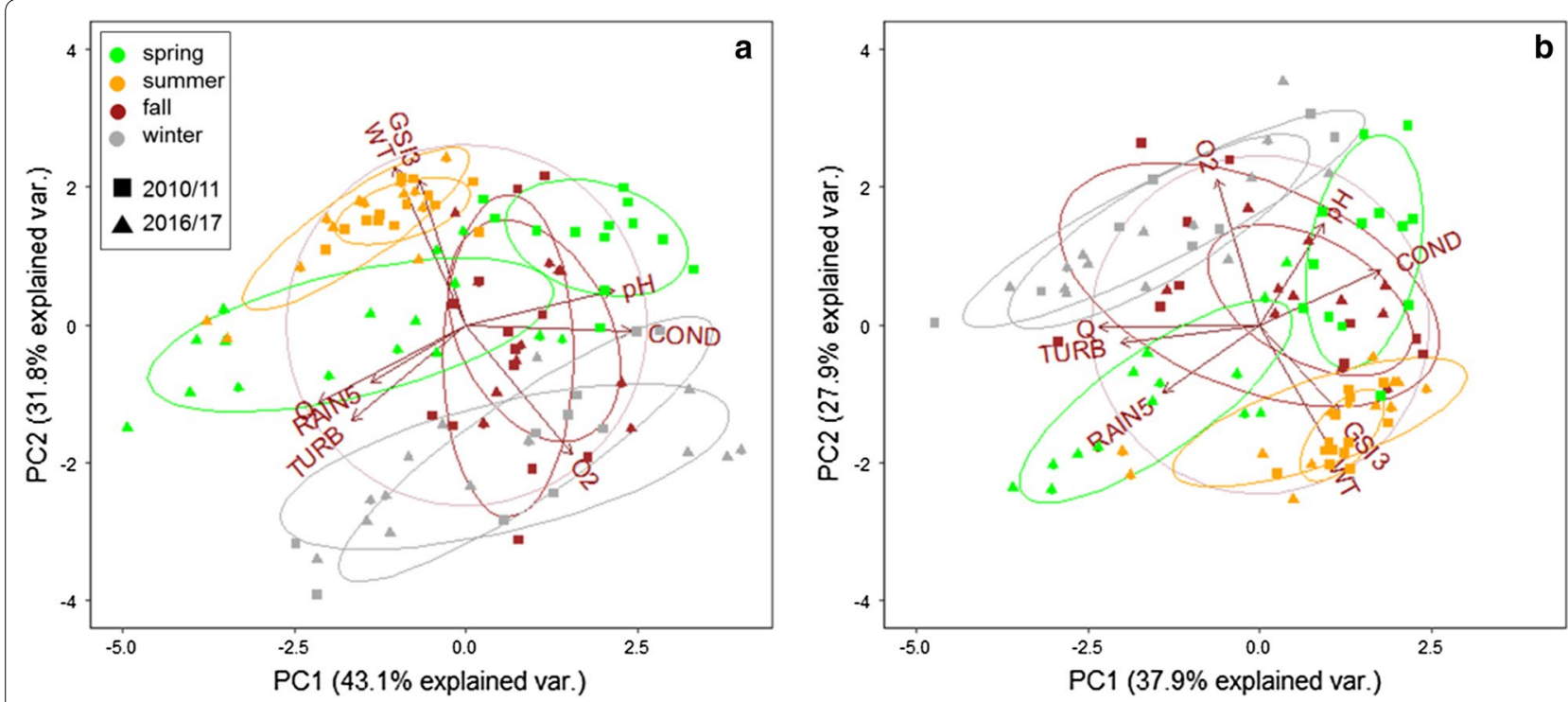

Fig. 3 PCA biplots of measured environmental parameters in river Rhine (a) and river Moselle (b) grouped by seasons. Squares: observations of sampling campaign 1 (2010/11); triangles: observations of sampling campaign 2 (2016/17). Circles: correlation circles; ellipses: normal probability ellipsoids. 3d-Sum of global solar irradiance (GSI3), water temperature (WT), conductivity (COND), turbidity (TURB), dissolved oxygen $\left(\mathrm{O}_{2}\right)$, and $5 d$-sum of rainfall (RAIN5)

Table 2 Spearman's rank correlations between environmental parameters and FIO concentrations in rivers Rhine and Moselle, respectively

\begin{tabular}{lllllllll}
\hline & Water temp & $\mathbf{p H}$ & Conductivity & $\mathbf{G S I}_{(\mathbf{3 d - s u m})}$ & RAIN $_{\text {(5d-sum) }}$ & $\mathbf{O}_{\mathbf{2}}$ & Turbidity $^{\text {Discharge }}$ \\
\hline Rhine & & & & & & & & \\
E. coli & -0.41 & -0.47 & -0.28 & -0.51 & 0.64 & 0.15 & 0.52 & 0.56 \\
Enterococci & -0.50 & -0.34 & -0.17 & -0.61 & 0.48 & 0.26 & 0.53 & 0.45 \\
Coliphages & -0.62 & -0.27 & -0.07 & -0.72 & 0.44 & 0.36 & 0.45 & 0.38 \\
Moselle & & & & & & & \\
E. coli & -0.25 & -0.38 & -0.27 & -0.30 & 0.47 & 0.12 & 0.60 & 0.52 \\
Enterococci & -0.22 & -0.45 & -0.22 & -0.34 & 0.49 & 0.06 & 0.53 & 0.45 \\
Coliphages & -0.70 & -0.31 & -0.43 & -0.58 & 0.41 & 0.41 & 0.54 & 0.77 \\
\hline
\end{tabular}

Correlation analyses were performed on the $z$-standardized data of the overall dataset including both sampling periods. Significant correlations ( $p<0.05$ ) are shown in italics

FIO concentrations increased with increasing rainfall, while they decreased with increasing global solar irradiance. This was in conformity to results of overall correlation analyses (Table 2). As mentioned earlier, conductivity contributed to the explanation of FIO concentrations in both rivers solely under low-flow conditions (Fig. 4a, c).

Despite the overall correlations with water temperature, its importance as an explaining factor in the RDA models was limited to the Moselle sampling site during low-flow conditions (Fig. 4c). Temperature was negatively connected to coliphages and to lesser extents to bacterial indicators. During both sampling campaigns, $\mathrm{pH}$ contributed to the explanation of FIO concentrations in the Moselle-site RDA models. Bacterial FIO were more strongly related to $\mathrm{pH}$ than coliphages (Fig. 4c, d).

For the Rhine, RDA models explained 74\% (2010/11) and $72 \%(2016 / 17)$ of observed variance, respectively. In River Moselle, $81 \%$ of variance was explained by the RDA model for the 2016/17 sampling campaign. The Moselle site RDA model for 2010/11 data showed the least explained variance with only $55 \%$, indicating that additional factors ruling FIO variation in 2010/11 were not considered. 

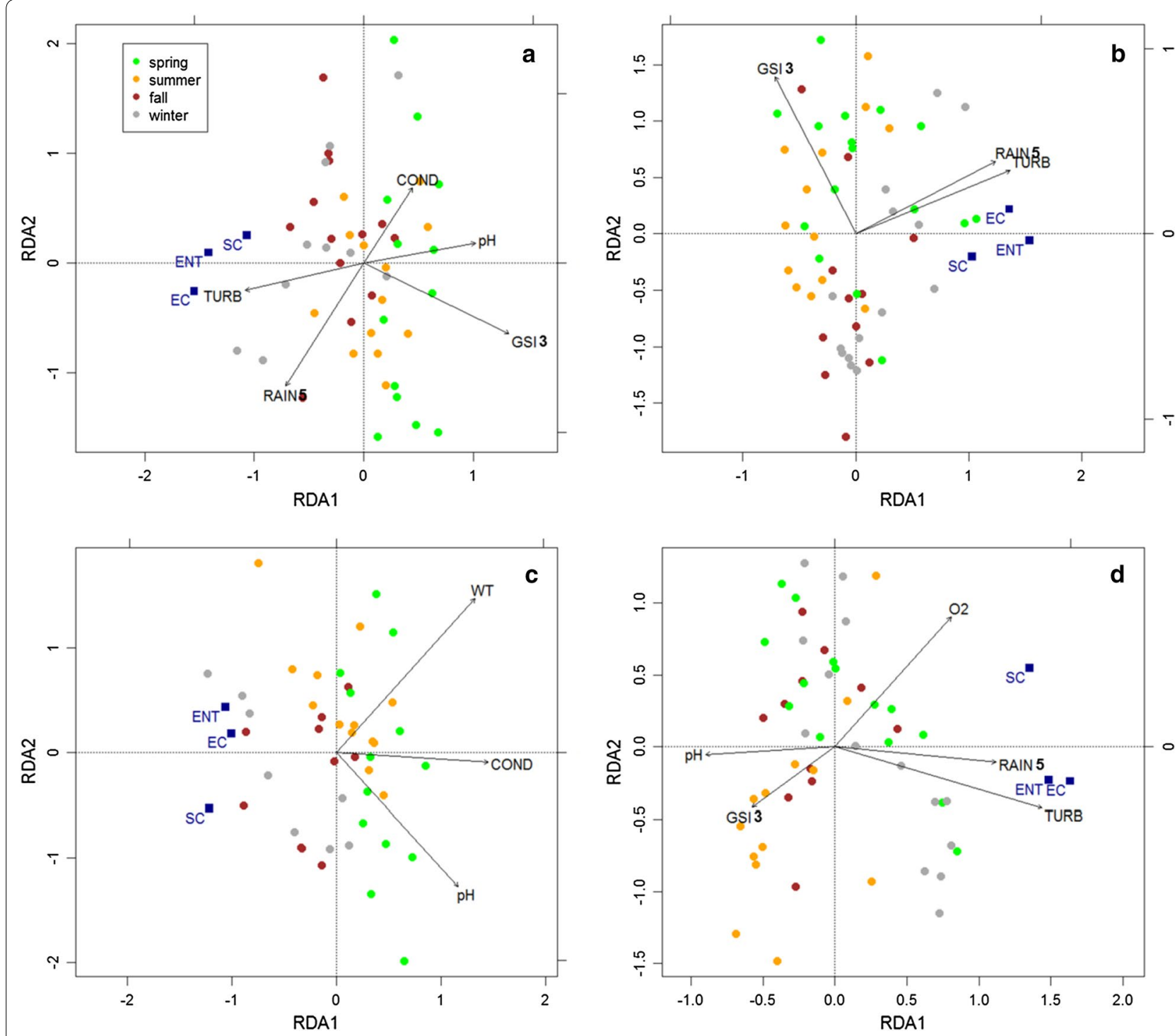

Fig. 4 RDA biplot of FIO and environmental parameters in river Rhine [a sampling campaign 1 (2010/2011); b sampling campaign 2 (2016/2017)] and in river Moselle [c sampling campaign 1 (2010/2011); d sampling campaign 2 (2016/2017)]. Environmental parameters are represented by black arrows and FIO by blue squares. 3d-Sum of global solar irradiance (GSI3), water temperature (WT), conductivity (COND), turbidity (TURB), dissolved oxygen $\left(\mathrm{O}_{2}\right)$, 5d-sum of rainfall (RAIN5), E. coli (EC), intestinal enterococci (ENT), and somatic coliphages (SC). Solely environmental variables that significantly explained variability in FIO concentrations were fitted to the ordination (arrows)

\section{Transferability of models and predicted microbial water quality}

Statistically valid models able to predict bathing water quality and fulfilling the required percentage coverage criteria could be built for Rhine based on discharge, rainfall, and global solar irradiance as explanatory variables. A goodness-of-fit $\left(R^{2}\right)$ of 0.73 was achieved when models were fitted with all data including both sampling campaigns. An overview of model validation is provided in Additional file 1: Figure S5. When fitted with data of sampling campaign 1 (2010/11), the Rhine site models reached $R^{2}=0.76$ and $R^{2}=0.65$ when fitted with data of sampling campaign $2(2016 / 17)$.

The goodness-of-fit for the Moselle site models fitted with all data was considerably lower $\left(R^{2}=0.55\right)$ compared to the Rhine site. When fitted with data of sampling campaign $1(2010 / 11), R^{2}$ reached 0.57 and 0.76 when fitted with data of sampling campaign 2 (2016/17). However, none of the Moselle site models did generate satisfactory results when validated against the data of the respective other year. They were not statistically valid as they did not fulfill model assumptions. Thus, despite their positive 
correlation with FIO, discharge and global solar irradiance provided only marginal improvements of the model's explained variance to the Moselle site data, while the goodness-of-fit of the Rhine site models was enhanced by incorporating discharge and global solar irradiance.

For the Rhine site, it was neither the model with the highest $R^{2}$ nor the one selected to be optimal by forward selection [based on the Akaike Information Criterion (AIC) as selection criterion] but a model less favorable, which was able to fulfill all percentage coverage criteria to satisfactorily predict microbial water quality.

Time series plots of predicted bathing water quality at the Rhine site in 2010/11 and 2016/17 are shown in Additional file 1: Figure S6. No plots are shown for the Moselle site as the applied criteria were not met.

\section{Discussion}

\section{Seasonality and importance of environmental factors} on fecal indicator concentrations

Environmental parameters affect pathogen abundances in aquatic systems in different ways under changing hydrological, biological, hydrogeochemical, and meteorological conditions. This study quantifies these varying environmental controls and provides a concept of how they can be used to predict bathing water quality in rivers.

In general, all FIO followed a similar pattern in both rivers. They showed strong intra- and inter-annual variations within the same river system due to various environmental interactions and seasonality of ambient environmental conditions, including water temperature, $\mathrm{pH}$, conductivity, global solar irradiance, rainfall, $\mathrm{O}_{2}$, turbidity, and discharge.

The Rhine is impounded only in its upper part, and else characterized by a free-flowing regime with considerably higher flow velocities compared to the Moselle at least under low-flow conditions. The average flow velocity of the Moselle, in contrast, is reduced through impoundments. This is reflected by statistical analyses, which implied that hydrological parameters have a more important influence on FIO concentrations in the Rhine even under low-flow conditions.

The correlation of FIO and turbidity can be attributed to the capacity of the increased flow rate to re-suspend sediments [20], which can considerably increase fecal bacteria and pathogen levels [21-23].

As indicated by the results of the correlation and RDA analyses, conductivity is a more influential factor in the Moselle compared to the Rhine. As mentioned earlier, the Moselle is characterized by elevated chloride concentrations [19]. However, effects of salt concentration on the decay of fecal bacteria are disputed in the literature [24-26]. Changes in conductivity because of rainfall events and rising water levels were more pronounced in the Moselle due to the river's smaller catchment, lower discharge, and elevated background conductivity levels. Correlations of FIO with conductivity most likely illustrated the effects of hydrodynamics on indicator concentrations rather than conductivity being a direct environmental driver itself.

\section{E. coli and enterococci}

A comparative analysis can reveal differences in relative numbers between bacterial and viral FIO, but also between bacterial FIO themselves. Data from the Moselle site during sampling campaign 1 exhibited the highest annual variation of bacterial FIO ratios and clearly pointed towards differential concentration changes in $E$. coli and enterococci. E. coli concentrations dominated in spring, whereas dominance of enterococci was observed in late summer. Relative differences between concentrations of $E$. coli and enterococci in aquatic environments have been described in previous studies. They were shown to be highly variable and depended on numerous factors, such as saline versus freshwater environments [27], the origin of the studied fecal indicator bacteria [28, 29], as well as stress factors such as sunlight [30], or grazing pressure [31].

\section{Somatic coliphages}

Variations in relative numbers further indicate a different behavior between fecal bacteria and phages. Phage replication or different sensitivities to environmental stresses were proposed as potential reasons [32].

As replication of somatic coliphages in surface waters is highly unlikely, it is not expected to influence the numbers of somatic coliphages detected in aquatic environments [33].

In contrast to previous findings, correlation analyses in this study pointed to a stronger negative relationship between phages and global solar irradiance compared to bacterial FIO. Moreover, phages were negatively correlated with temperature. Sinton et al. [29] had shown that bacterial FIO are less sunlight resistant than coliphages. In our study, the observed distinct relationship of phages with global solar irradiance was most likely related to changes in temperature as both parameters were strongly correlated themselves. This is corroborated by a stronger relationship of somatic coliphages with high $\mathrm{O}_{2}$ (Rhine: $r=0.36$, Moselle: $r=0.41$ ) concentrations compared to bacterial indicators $(r=0.26$ for enterococci in the Rhine, others not significant). Despite decreasing water temperature and rising discharge in winter, coliphage concentrations (normalized to discharge) tended to remain high in both rivers, whereas bacteria concentrations declined. A direct effect of $\mathrm{O}_{2}$ levels on concentrations of enteric 
organisms in water environments is unlikely. Previous studies indicated almost no $\mathrm{O}_{2}$ sensitivity of FIO [34].

As elevated $\mathrm{O}_{2}$ contents occur particularly in winter based on the capability of cold water to dissolve more oxygen, the negative relationship between phage and $\mathrm{O}_{2}$ concentrations was mainly caused by water temperature, further strengthening the assumption that phage concentrations are less affected by low temperatures than those of bacteria.

\section{Global solar irradiance and water temperature}

Generally, a positive correlation of gastrointestinal bacteria with water temperature would be expected. Thus, negative correlations between FIO and water temperature point towards strong influences of other environmental factors. The dependency is possibly masked by the opposing effect of global solar irradiance, considering that global solar irradiance and water temperature are interrelated themselves.

In spring and summer, solar irradiation causes a rise in water temperature and temperature in turn enhances predation rates by protozoa (e.g., grazing) [35-37]. This could have contributed to the negative interdependency of water temperature and FIO concentrations in this study.

\section{$\mathrm{pH}$ and $\mathrm{O}_{2}$ as a function of phytoplankton production} Phytoplankton fixes $\mathrm{CO}_{2}$ for photosynthesis. Assimilation of inorganic carbon by dense phytoplankton blooms can deplete the dissolved $\mathrm{CO}_{2}$ concentration in surface waters, thus causing an increase in $\mathrm{pH}$ [38]. Elevated $\mathrm{pH}$ values were measured in particular in the Moselle under low-flow conditions during spring 2010/11. Distinct interdependencies of $\mathrm{pH}$, chlorophyll $a$, and $\mathrm{O}_{2}$ (due to $\mathrm{O}_{2}$ production by photosynthesis) were observed in the Moselle, highlighting the strong connection between $\mathrm{pH}$ values and processes related to primary production at this site. Notably, phytoplankton abundance is generally higher in the Moselle compared to the Rhine [39]. Increased $\mathrm{pH}$ levels in the Moselle during the first sampling campaign were more influenced by phytoplankton growth, linking losses in FIO concentrations to primary production processes. Although some impact of alkaline $\mathrm{pH}$ on the inactivation of bacterial FIO can be anticipated [40], it is unlikely that the variance in indicator concentrations is exclusively owed to a direct effect of $\mathrm{pH}$ alone.

\section{Grazing}

Besides more alkaline $\mathrm{pH}$ values, phytoplankton blooms are known to coincide with annual proto- and metazooplankton peaks in both river systems [39]. However, previous research showed that the increase in zooplankton biomass is much more pronounced in the Moselle [39].
Protozoan grazing is known to be an important topdown control of bacterial populations in aquatic environments (e.g., [25, 41, 42]).

Grazing is size selective [43] and most protists graze preferentially on medium-sized bacterial cells [44]. Although there is evidence that some flagellates are able to feed on phages and viruses [45], they are likely grazed on to a lesser extent than bacteria and can, therefore, be described more precisely by hydrological and meteorological factors. This is further supported by the calculated relative differences between viral and bacterial FIO (Additional file 1: Figure S3) as well as by correlation analyses among the different types of indicators. While behavior of $E$. coli, enterococci, and coliphages in the Rhine is quite similar, dynamics of coliphages and bacteria differ considerably at the Moselle site, particularly under low-flow conditions.

Conclusively, grazing instead of $\mathrm{pH}$ is most likely responsible for the loss of fecal bacteria in the Moselle based on the higher secondary productivity. Because grazing is not accounted for as an explanatory factor in the statistical analyses, the proportion of unexplained variance in the FIO data for sampling campaign 1 (with higher phyto- and zooplankton abundances) is higher than for sampling campaign 2, and linear regression models failed in the Moselle where zooplankton abundance was higher than in the Rhine.

\section{Model application, transferability, and implications for water quality predictions}

Parameters such as global solar irradiance, water temperature, discharge, and rainfall were shown to be influential and can be regarded as relevant input parameters for predictive modelling of microbial water quality. These relations have already been described for different environments and were applied with varying success in multiple modelling approaches for other aquatic settings (e.g., [15]). For example, discharge, rainfall, and global solar irradiance contributed significantly to explained variance in multiple linear regression models for the Lahn River [11] and proved to be suitable explanatory parameters in the Bayesian linear regression model predicting E. coli concentrations in the Rhine in this study.

It remains to be tested whether wastewater treatment plant discharge data as key explanatory variable further enhances model performance at the studied sites.

Not surprisingly, model accuracy and parameter selection were highly dependent on the study site. Contributions of key processes varied site specifically by season, year, and type of FIO. Therefore, relations of FIO and environmental factors cannot be applied unrestrictedly to spatially separated sites or different river systems. 
With regard to the overall model validation and assessment approach, the applied test criteria were restrictive enough to avoid model overfitting. This prevents the application of predictive modelling for bathing water management at recreational water activity sites where environmental conditions are much more complicated than captured by model assumptions. Similar to the previously studied site in Berlin [13], it was neither the model with the highest $R^{2}$ nor the one selected to be optimal by forward selection (based on the AIC as selection criterion) but a model less favorable which was able to fulfill all percentage coverage criteria to satisfactorily predict microbial water quality at the Rhine sampling site. This shows that the application of these validation criteria provides a reasonable additional criterion to be applied for model validation in water management situations with human health implications.

Considering the variations in the strengths of relations between environmental parameters and FIO concentrations across various years, a model fitted only with data of low-flow conditions, for example, is not capable of generating the same predictive accuracy when applied for high-flow conditions and vice versa. However, this information can be used for targeted monitoring campaigns aiming specifically at conditions for which reliable data are lacking. To account for changing conditions and variations in contributions of environmental factors, it is recommended to use more than 1 year of data including a broad range of environmental situations for model calibration.

Due to the Rhine's free flowing regime, models based on hydrological parameters provided more satisfactory estimates for this river. As FIO losses due to grazing most likely accounted for a large proportion of unexplained variance in the Moselle site models, incorporating grazing related parameters into modelling approaches for specific river types where trophic interactions are more influential than hydrological dynamics could enhance modelling success.

Accounting for seasonality may also enhance model performance. Coliphages show a less overall variability and represent a more suitable response variable in multiple linear regression models for rivers with pronounced trophic interactions. Their concentrations can be sufficiently described by hydrological and meteorological variables alone. At the moment, no viral FIO is included in the EBWD [7]. Nevertheless, the findings of this investigation indicate that phages (as model organisms for viruses) behave considerably different than bacteria under certain environmental conditions. Especially during spring and winter times, solely assessing bacterial FIO can lead to an underestimation of virus loads in rivers with long water residence times and pronounced trophic interactions. Therefore, additional integration of indicators for viral contamination in water quality monitoring should be considered.

\section{Conclusions}

- High-flow conditions generally favor the deterioration of microbial water quality in rivers.

- Exceptionally low-flow conditions enhance loss rates of FIO in rivers, especially in rivers with already prolonged water residence times and high phytoplankton abundances. Viral indicators show less pronounced loss rates than bacterial indicators under these conditions. Hence, viral contamination might be underestimated under such conditions (e.g., in spring and winter) if solely maximum permissible concentrations of bacterial indicators are considered as demanded by EBWD.

- High loss rates due to grazing activities impair accuracy of models based on hydro-meteorological parameters. Finding solutions for incorporating loss rates due to grazing may enhance model accuracy particularly for bacterial indicators as response variables in rivers with prolonged water residence time and strong trophic interactions.

- For rivers where trophic interactions prevail, viral indicators may pose a more reliable response variable in multiple linear regression models. For rivers where FIO concentrations are predominantly driven by hydro-meteorological factors, the Bayesian linear regression approach represents a valuable tool for water quality prediction.

\section{Materials and methods}

\section{Study sites and sampling}

The rivers Rhine and Moselle differ considerably in size, trophic state, hydrological conditions, and hydrochemical characteristics. The Rhine has a total length of $1230 \mathrm{~km}$ and a catchment area of about $200,000 \mathrm{~km}^{2}$, its major tributary Moselle a total length of $540 \mathrm{~km}$ and a catchment area of $28,000 \mathrm{~km}^{2}$, respectively. The sampling sites at the Rhine and the Moselle are located within a linear distance of approximately $3 \mathrm{~km}$ in the city of Koblenz, Germany, near the confluence of both rivers. Hence, comparable meteorological conditions can be expected at both sites. The Moselle sampling site is located $4 \mathrm{~km}$ upstream to the Moselle permanent monitoring station ( $\mathrm{rkm} 2$ ) providing continuous readings of relevant hydrochemical water quality parameters. Rhine water samples were obtained at the Rhine monitoring station, $590 \mathrm{~km}$ downstream of Lake Constance (Fig. 5). 


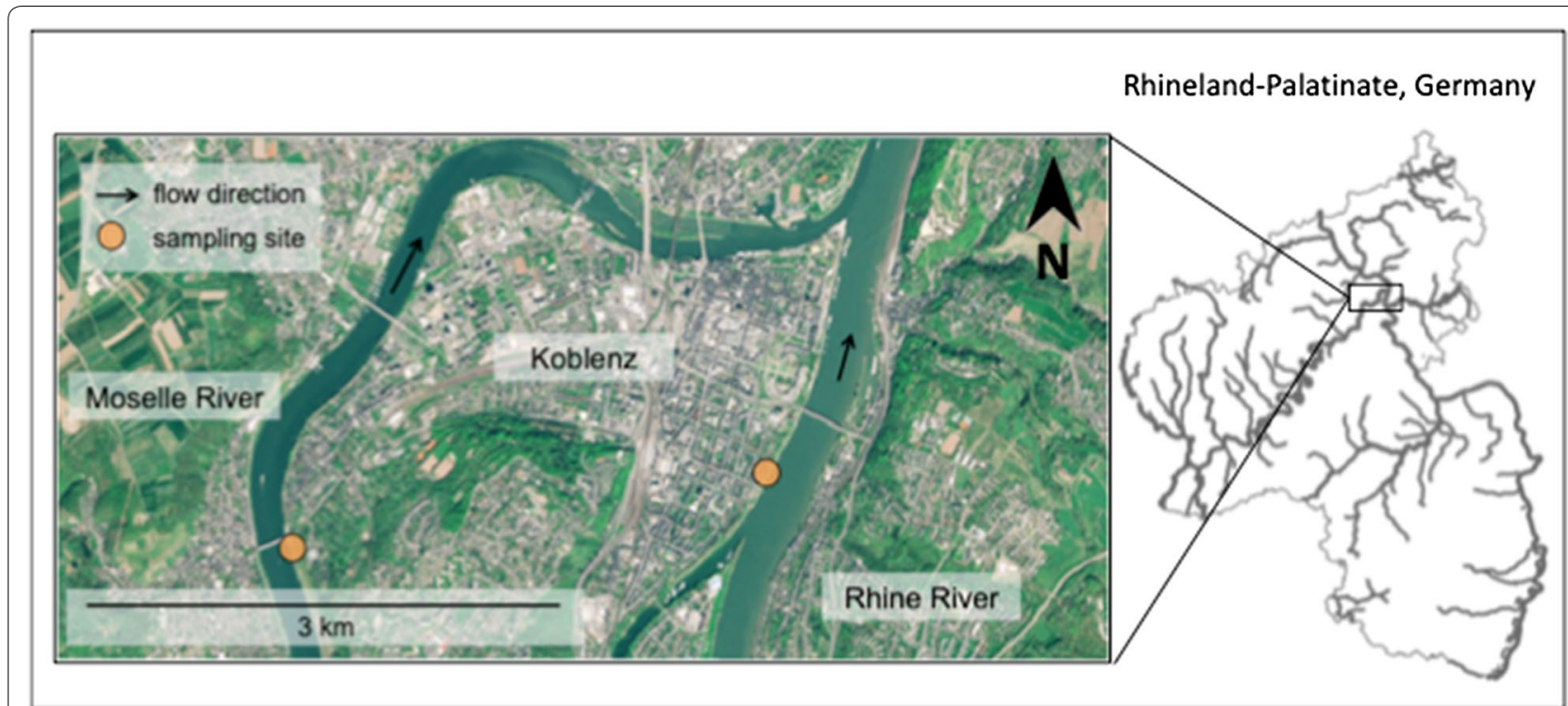

Fig. 5 Location of the sampling sites at river Rhine and river Moselle (modified from Federal Agency for Cartography and Geodesy, 2019, and https ://geoportal-wasser.rlp-umwelt.de/servlet/is/2025/)

At each sampling site, water samples $(1 \mathrm{~L}$ volume) were collected once a week from October 19th, 2010 until October 19th, 2011 (sampling campaign 1), and from January 13th, 2016, until January 25th, 2017 (sampling campaign 2), according to standardized procedures [46]. All samples were processed immediately upon arrival in the laboratory (i.e., within 2-3 h after sampling). Sampling period 1 was characterized by remarkably low discharges especially in March and May, as well as in November 2011 [47]. Sampling period 2 in contrast was characterized by heavy precipitation events resulting in rising water levels and floods during spring [48].

\section{Analysis of fecal indicators}

A total of 211 water samples were analyzed for $E$. coli, intestinal enterococci, and somatic coliphages as described in Herrig et al. [11]. In brief, concentrations of E. coli were estimated following the most probable number (MPN) approach [49]. All tests were performed using standardized microtiter plates according to the manufacturer's instructions and product-specific MPN tables (Dr. Brinkmann Floramed, Nürtingen, Germany). Intestinal enterococci were quantified via membrane filtration on Pall GN-6 Metricel mixed cellulose esters filters (ø $47 \mathrm{~mm}$, porosity $0.45 \mu \mathrm{m}$ ), followed by cultivation on Slanetz-Bartley agar and subsequent colony confirmation using bile esculin agar [50]. Depending on expected cell concentrations, sample volumes ranged from 1 to $100 \mathrm{~mL}$. Volumes $<10 \mathrm{~mL}$ were supported by the addition of sterile peptone salt solution.
Somatic coliphages were quantified via the phage plaque test for samples with expected low concentrations of phages [51]. Nalidixic acid (final concentration $250 \mu \mathrm{g} /$ $\mathrm{mL}$ ) was added to minimize effects due to the microbial background flora. The nalidixic acid-resistant E. coli strain ATCC 700078 (American Type Culture Collection) was used as the host.

\section{Hydrochemical parameters and meteorological data}

Daily mean water discharge data were derived from recorded water gauges at Cochem (Moselle) and Kaub (Rhine). Daily averages of continuously measured hydrochemical parameters including ambient water temperature, $\mathrm{O}_{2}$ concentrations, $\mathrm{pH}$, turbidity, and conductivity were obtained from nearby permanent monitoring stations operated by the Federal Institute of Hydrology (BfG). In addition, $\mathrm{pH}$, conductivity, and water temperature were also measured in situ during indicator sampling using portable field probes (MultiLine F/Set-3, WTW, Germany). Daily rainfall and global solar irradiance data derived from surrounding official weather stations (Valwig, Winningen, Mayen, Mülheim-Kärlich, Bingen-Gaulsheim, and Bacharach) were obtained from Agrarmeteorologie Rhineland-Palatinate (http://www. wetter.rlp.de). Chlorophyll $a$ concentrations were determined using German Standard Methods [52]. Briefly, phytoplankton was filtered on Whatman GF 6 glass-fiber filters and pigments were extracted with hot ethanol. Chlorophyll $a$ concentration was determined photometrically (DR 2800, Hach Lange, Germany). 


\section{Statistical analyses of environmental factors and FIO concentrations}

Data were analyzed using the Statistical Software $R$ [53]. Prior to statistical analysis, mean daily rainfall and global solar irradiance data of all six surrounding weather stations were combined. Subsequently, hydrochemical parameters as well as weather data were binned to account for variable time intervals inbetween weekly samplings. In detail, the daily mean values of water discharge, water temperature, $\mathrm{pH}$, conductivity, and $\mathrm{O}_{2}$ were summed over the number of days (i.e., 1 to 7 days) preceding the day of sampling. For rainfall and global solar irradiance, sums were calculated correspondingly, resulting in seven data sets for each of these variables. Missing values of hydrochemical parameters obtained from the permanent monitoring stations (e.g., due to sensor failures) were replaced by data from in situ measurements that accompanied each indicator monitoring campaign. Assignment of seasons (spring, summer, fall, winter) followed the astronomical beginning of seasons for the Central European Time Zone (UTC +1$)$.

For $E$. coli, levels below the detection limit of the MPN method (i.e., < $15 \mathrm{MPN} / 100 \mathrm{~mL}$ ) were treated as half the detection limit during statistical analysis (i.e., 7.5 MPN/100 mL). Intestinal enterococci values outside the quantification range (i.e., in cases where excessive growth did not allow counting of colonies) were omitted for further statistical analyses.

Spearman's rank correlation analyses were performed on the $z$-standardized data to investigate relationships between FIO and individual environmental variables.

Opposed to sampling campaign 2, the exact days of chlorophyll $a$ and FIO samplings differed in campaign 1. Hence, correlations of chlorophyll $a$ with daily measured $\mathrm{pH}$ and $\mathrm{O}_{2}$ were investigated separately.

Principal component analyses (PCA) and redundancy analyses (RDA) were performed on normalized $\left[y^{\prime}=\log 10(y+1)\right]$ and $z$-standardized data, to account for different scales. PCA was calculated using the prcomp() command implemented in the stats package [53]. Results were visualized by use of the ggbiplot package [54]. Environmental factors explaining FIO concentrations with the best fit were identified in RDA by automatic stepwise model building applying the ordistep() command, which chooses a model by permutation tests (vegan package) [55]. Statistical significance of the final RDA model was tested by ANOVA. Models were checked for collinearity by calculating the variance inflation factor (VIF). A locally weighted scatterplot smoothing (LOESS) function was used to discern annual trends in FIO ratios using the geom_smooth() function in the ggplot2 package [56].

\section{Bayesian linear regression approach}

To evaluate the potential transferability of model assessment and validation approaches between different river systems, a Bayesian approach for regression modelling by Seis et al. [13] was applied to the Moselle and Rhine site datasets. In this approach, a linear regression model is fitted on the $\log _{10}$-transformed indicator data and the predicted mean and residual standard deviation are used to construct a lognormal probability density function to meet the demands of the EBWD. The constructed density function is referred to as the posterior predictive distribution and the $95 \%$ prediction interval as the $95 \%$ credible interval of the posterior predictive distribution. After checking the model for normality and heteroscedasticity of residuals, model predictions are validated by percentage coverage, i.e., $95 \%$ of the validation data should fall within the $95 \%$ credible interval and below the 95th percentile of the posterior predictive distribution, and $90 \%$ of the validation data should fall below the 90th percentile. If more than one valid model can be developed, preference is given to the model with the lower "leave one out cross validation information criterion" (LOO-IC). Models presented in this study were fitted with the 2010/11 data and validated against the data from 2016/2017 and vice versa. For rainfall as explanatory variable, a natural logarithm transformation was applied. Explanatory variables were selected through forward selection allowing for interaction between variables and limiting the number of variables to (a) N/10, if the number of data points was below 100 and (b) 10, if the number of data points was larger than 100. Each model of the forward selection process was saved and tested against the above-mentioned percentage coverage criteria. Valid models were tested for the most critical assumptions with the Shapiro-Wilk test for normality [57] and for constant variance (homoscedasticity) by the Breusch-Pagan test against heteroscedasticity [58]. In contrast to the study by Seis et al. [13], wastewater treatment plant discharge data were not considered as explanatory variables, but additional prediction variables such as $\mathrm{pH}$ and $\mathrm{O}_{2}$ were incorporated.

\section{Supplementary information}

Supplementary information accompanies this paper at https://doi. org/10.1186/s12302-019-0250-9.

Additional file 1: Figure S1. Mean daily electrical conductivity in dependence of discharge in rivers Rhine (A) and Moselle (B) throughout sampling campaign 1 (2010/11) and 2 (2016/17). Figure S2. PCA biplots of FIO concentrations in river Rhine (A: sampling campaign 1 (2010/11), B: sampling campaign $2(2016 / 17))$ and river Moselle (C: sampling campaign 1 (2010/11), D: sampling campaign 2 (2016/17)) grouped by seasons. Circles: correlation circles, ellipses: normal probability ellipsoids. E. coli (EC), intestinal enterococci (ENT), somatic coliphages (SC). Figure S3. Ratios of FIO concentrations (circles) in river Rhine (A: sampling campaign 1 (2010/2011); B: sampling campaign 2 (2016/2017)) and river 
Moselle (C: sampling campaign 1 (2010/2011); D: sampling campaign 2 (2016/2017)). A locally weighted scatterplot smoothing (LOESS) function (lines) was used to discern annual trends. Red circles represent calculated ratios of E. coli: enterococci (EC:ENT), green circles E. coli: phages (EC:SC), and blue circles enterococci: phages (ENT:SC). Figure S4. Boxplots of seasonal fecal indicator concentrations normalized to discharge in river Rhine (A) and river Moselle (B) including observations of both sampling campaigns. Figure $\mathbf{S 5}$. Tests of model assumptions for the Rhine site model fitted with data of both sampling campaigns. Figure S6. Time series plots for the Rhine site Bayesian linear regression models with model equations. (A) Predicted $\log _{10}$ E. coli concentrations for sampling campaign 1 (2010/2011) when trained with data from sampling campaign 2 (2016/2017) and (B) Predicted $\log _{10}$ E. coli concentrations for sampling campaign 2 (2016/2017) when trained with data from campaign 1 (2010/2011). Grey area: posterior predictive distribution, green circles: validation data (not used for model fitting). White horizontal lines indicate the percentile threshold for sufficient bathing water quality of 900 MPN/100 mL.

\section{Abbreviations}

AIC: Akaike Information Criterion; ATTC: American Type Culture Collection; avg: average; BfG: Federal Institute of Hydrology (Bundesanstalt für Gewässerkunde); BMBF: Federal Ministry for Education and Research (Bundesministerium für Bildung und Forschung); BMVI: Federal Ministry of Transport and Digital Infrastructure (Bundesministerium für Verkehr und digitale Infrastruktur); CFU: colony-forming units; COND: conductivity; EBWD: European Bathing Water Directive; EC: Escherichia coli; ENT: intestinal enterococci; FIO: fecal indicator organism(s); GSI: global solar irradiance; ISO: International Standardization Organization; LOO-IC: "leave one out cross validation information criterion"; MPN: most probable number; $\mathrm{O}_{2}$ : dissolved oxygen; PC: principal component; PCA: principal component analysis; PFU: plaque-forming units; PPD: posterior predictive distribution; Q: discharge; R: Statistic Software R; RDA: redundancy analysis; SC: somatic coliphages; SD: standard deviation; Temp: temperature; TURB: turbidity; VIF: variance inflation factor; WT: water temperature.

\section{Acknowledgements}

We would like to acknowledge Bianca Konrath, Jessica Tepper, and Johannes Lingen for excellent assistance with sampling and laboratory analyses.

\section{Authors' contributions}

$\mathrm{HF}, \mathrm{SB}$, and WM devised the projects and the main conceptual ideas. IH and SB collected the data. $1 \mathrm{H}$ performed laboratory analyses, analyzed the data and wrote the manuscript. WS established Bayesian regression models and contributed to the manuscript. JR participated in interpreting the results as well as drafting and critically revising the manuscript. HF, WM, SB and GR provided feedback on the manuscript and results. All authors read and approved the final manuscript.

\section{Funding}

This study was part of the research program KLIWAS ("Impacts of climate change on waterways and navigation-Searching for options of adaptation") funded by the Federal Ministry of Transport and Digital Infrastructure (Bundesministerium für Verkehr und digitale Infrastruktur, BMVI) and the project FLUSSHYGIENE ("Hygienically relevant microorganisms and pathogens in multifunctional surface water and water cycles: sustainable management of different river types in Germany") funded by the Federal Ministry for Education and Research (Bundesministerium für Bildung und Forschung, BMBF) under sponsorship number 02WRS1278A.

\section{Availability of data and materials}

The weather data (e.g., rainfall, global solar irradiance) that support the findings of this study are available from the Centers of Rural Services in RhinelandPalatinate, Germany under https://www.wetter.rlp.de/.

Daily averages of continuously measured hydrochemical parameters (e.g., water temperature, $\mathrm{O}_{2}$ concentrations, $\mathrm{pH}$, turbidity, conductivity) can be requested from the Federal Institute of Hydrology (BfG).

The datasets generated by the authors during the study are not publicly available but can be made available upon reasonable request.
Ethics approval and consent to participate

Not applicable.

\section{Consent for publication}

Not applicable.

\section{Competing interests}

The authors declare that they have no competing interests.

\section{Author details}

1 Department G3-Biochemistry, Ecotoxicology, Federal Institute of Hydrology, 56068 Koblenz, Germany. ${ }^{2}$ Department of Biology, Institute for Integrated Natural Sciences, University of Koblenz-Landau, 56070 Koblenz, Germany. ${ }^{3}$ Kompetenzzentrum Wasser Berlin gGmbH, 10709 Berlin, Germany. ${ }^{4}$ Delft University of Technology, 2628 CD Delft, The Netherlands. ${ }^{5}$ Department U2-Microbial Ecology, Federal Institute of Hydrology, 56068 Koblenz, Germany. ${ }^{6}$ Present Address: LUFA Nord-West, Institute for Food Quality, 26129 Oldenburg, Germany.

Received: 24 May 2019 Accepted: 22 August 2019

Published online: 23 September 2019

References

1. King S, Exley J, Winpenny E et al (2015) The health risks of bathing in recreational waters: a rapid evidence assessment of water quality and gastrointestinal illness. RAND Eur, Cambridge

2. Sanborn M, Takaro T (2013) Recreational water-related illness: office management and prevention. Can Fam Physician 59:491-495

3. Francy DS, Stelzer EA, Duris JW et al (2013) Predictive models for Escherichia coli concentrations at inland lake beaches and relationship of model variables to pathogen detection. Appl Environ Microbiol 79:1676-1688. https://doi.org/10.1128/AEM.02995-12

4. Vermeulen $L C$, Hofstra $N(2014)$ Influence of climate variables on the concentration of Escherichia coli in the Rhine, Meuse, and Drentse Aa during 1985-2010. Reg Environ Change 14:307-319. https://doi.org/10.1007/ s10113-013-0492-9

5. Cho KH, Cha SM, Kang J-H et al (2010) Meteorological effects on the levels of fecal indicator bacteria in an urban stream: a modeling approach. Water Res 44:2189-2202. https://doi.org/10.1016/j.watres.2009.12.051

6. Clark ML, Norris JR (2000) Occurrence of fecal coliform bacteria in selected streams in Wyoming, 1990-99. US Geological Survey

7. Commission European (2006) Directive 2006/7/EC of the European Parliament, concerning the management of bathing water quality and repealing directive 76/160/EEC. Off J Eur Communities 64:37-51

8. Skraber S, Gassilloud B, Gantzer C (2004) Comparison of coliforms and coliphages as tools for assessment of viral contamination in river water. Appl Environ Microbiol 70:3644-3649. https://doi.org/10.1128/ AEM.70.6.3644-3649.2004

9. Nevers MB, Whitman RL (2011) Efficacy of monitoring and empirical predictive modeling at improving public health protection at Chicago beaches. Water Res 45:1659-1668. https://doi.org/10.1016/j.watre s.2010.12.010

10. Mas DML, Ahlfeld DP (2007) Comparing artificial neural networks and regression models for predicting faecal coliform concentrations. Hydrol Sci J 52:713-731. https://doi.org/10.1623/hysj.52.4.713

11. Herrig IM, Böer SI, Brennholt N, Manz W (2015) Development of multiple linear regression models as predictive tools for fecal indicator concentrations in a stretch of the lower Lahn River, Germany. Water Res 85:148-157. https://doi.org/10.1016/j.watres.2015.08.006

12. Kay D, Wyer M, Crowther J et al (2005) Predicting faecal indicator fluxes using digital land use data in the UK's sentinel Water Framework Directive catchment: the Ribble study. Water Res 39:3967-3981

13. Seis W, Zamzow M, Caradot N, Rouault P (2018) On the implementation of reliable early warning systems at European bathing waters using multivariate Bayesian regression modelling. Water Res 143:301-312. https //doi.org/10.1016/j.watres.2018.06.057

14. Nevers MB, Boehm AB (2011) Modeling fate and transport of fecal bacteria in surface water. In: Sadowsky MJ, Whitman RL (eds) The fecal bacteria. American Society of Microbiology, Washington, pp 165-188 
15. de Brauwere A, Ouattara NK, Servais P (2014) Modeling fecal indicator bacteria concentrations in natural surface waters: a review. Crit Rev Environ Sci Technol 44:2380-2453. https://doi.org/10.1080/10643 389.2013.829978

16. Pachepsky YA, Shelton DR (2011) Escherichia coli and fecal coliforms in freshwater and estuarine sediments. Crit Rev Environ Sci Technol 41:1067-1110. https://doi.org/10.1080/10643380903392718

17. Pandey PK, Kass PH, Soupir ML et al (2014) Contamination of water resources by pathogenic bacteria. AMB Express 4:51. https://doi. org/10.1186/s13568-014-0051-x

18. Wilkes G, Edge TA, Gannon VPJ et al (2011) Associations among pathogenic bacteria, parasites, and environmental and land use factors in multiple mixed-use watersheds. Water Res 45:5807-5825. https://doi. org/10.1016/j.watres.2011.06.021

19. Beisel J-N, Peltre M-C, Usseglio-Polatera P (2011) Einfluss der Salzbelastung auf die aquatische Biozönose der Mosel. Abschlussbericht des Labors LIEBE im Auftrag der IKSMS. http://www.iksms.de/servlet/ is/20088/. Accessed 19 Aug 2019

20. Wilkinson J, Jenkins A, Wyer M, Kay D (1995) Modelling faecal coliform dynamics in streams and rivers. Water Res 29:847-855. https://doi. org/10.1016/0043-1354(94)00211-O

21. Cho KH, Pachepsky YA, Kim JH et al (2010) Release of Escherichia coli from the bottom sediment in a first-order creek: experiment and reach-specific modeling. J Hydrol 391:322-332

22. Muirhead RW, Davies-Colley RJ, Donnison AM, Nagels JW (2004) Faecal bacteria yields in artificial flood events: quantifying in-stream stores. Water Res 38:1215-1224. https://doi.org/10.1016/j.watres.2003.12.010

23. Droppo IG, Liss SN, Williams D et al (2009) Dynamic existence of waterborne pathogens within river sediment compartments. Implications for water quality regulatory affairs. Environ Sci Technol 43:1737-1743. https://doi.org/10.1021/es802321w

24. Davies CM, Evison LM (1991) Sunlight and the survival of enteric bacteria in natural waters. J Appl Bacteriol 70:265-274

25. Menon P, Billen G, Servais P (2003) Mortality rates of autochthonous and fecal bacteria in natural aquatic ecosystems. Water Res 37:41514158. https://doi.org/10.1016/S0043-1354(03)00349-X

26. Anderson IC, Rhodes M, Kator H (1979) Sublethal stress in Escherichia coli: a function of salinity. Appl Env Microbiol 38:1147-1152

27. Anderson KL, Whitlock JE, Harwood VJ (2005) Persistence and differential survival of fecal indicator bacteria in subtropical waters and sediments. Appl Environ Microbiol 71:3041-3048. https://doi.org/10.1128/ AEM.71.6.3041-3048.2005

28. Korajkic A, McMinn BR, Harwood VJ et al (2013) Differential decay of enterococci and Escherichia coli originating from two fecal pollution sources. Appl Environ Microbiol 79:2488-2492. https://doi. org/10.1128/AEM.03781-12

29. Sinton LW, Hall CH, Lynch PA, Davies-Colley RJ (2002) Sunlight inactivation of fecal indicator bacteria and bacteriophages from waste stabilization pond effluent in fresh and saline waters. Appl Environ Microbiol 68:1122-1131. https://doi.org/10.1128/AEM.68.3.1122-1131.2002

30. Noble RT, Lee IM, Schiff KC (2004) Inactivation of indicator microorganisms from various sources of faecal contamination in seawater and freshwater. J Appl Microbiol 96:464-472. https://doi.org/10.111 1/j.1365-2672.2004.02155.x

31. Ayo B, Santamaria E, Latatu A et al (2001) Grazing rates of diverse morphotypes of bacterivorous ciliates feeding on four allochthonous bacteria. Lett Appl Microbiol 33:455-460. https://doi.org/10.1046/ j.1472-765X.2001.01034.X

32. Contreras-Coll N, Lucena F, Mooijman Ket al (2002) Occurrence and levels of indicator bacteriophages in bathing waters throughout Europe. Water Res 36:4963-4974. https://doi.org/10.1016/S0043-1354(02)00229-4

33. Jofre J (2009) Is the replication of somatic coliphages in water environments significant? J Appl Microbiol 106:1059-1069. https://doi.org/10. 1111/j.1365-2672.2008.03957.x

34. Pearson HW, Mara DD, Mills SW, Smallman DJ (1987) Physico-chemical parameters influencing faecal bacterial survival in waste stabilization ponds. Water Sci Technol 19:145-152. https://doi.org/10.2166/ wst.1987.0139

35. Vaqué D, Gasol JM, Marrasé C (1994) Grazing rates on bacteria: the significance of methodology and ecological factors. Mar Ecol Prog Ser 109:263-274
36. Sherr BF, Sherr EB, Rassoulzadegan F (1988) Rates of digestion of bacteria by marine phagotrophic protozoa: temperature dependence. Appl Environ Microbiol 54:1091-1095

37. Byappanahalli MN, Nevers MB, Korajkic A et al (2012) Enterococci in the environment. Microbiol Mol Biol Rev 76:685-706. https://doi.org/10.1128/ MMBR.00023-12

38. Wetzel RG (2001) Limnology: lake and river ecosystems. Academic Press, San Diego

39. Bergfeld T, Scherwass A, Ackermann B et al (2009) Comparison of the components of the planktonic food web in three large rivers (Rhine, Moselle and Saar). River Res Appl 25:1232-1250. https://doi.org/10.1002/rra.1217

40. Sinton LW (2005) Biotic and abiotic effects. Oceans and health: pathogens in the marine environment. Springer, Boston, pp 69-92

41. Boenigk J, Arndt H (2002) Bacterivory by heterotrophic flagellates: community structure and feeding strategies. Antonie van Leeuwenhoek 81:465-480

42. Weitere M, Scherwass A, Sieben K-T, Arndt H (2005) Planktonic food web structure and potential carbon flow in the Lower River Rhine with a focus on the role of protozoans. River Res Appl 21:535-549. https://doi.org/10.1002/ rra.825

43. Chrzanowski TH, Šimek K (1990) Prey-size selection by freshwater flagellated protozoa. Limnol Oceanogr 35:1429-1436. https://doi.org/10.4319/ lo.1990.35.7.1429

44. Hahn MW, Höfle MG (2001) Grazing of protozoa and its effect on populations of aquatic bacteria. FEMS Microbiol Ecol 35:113-121. https://doi. org/10.1111/j.1574-6941.2001.tb00794.x

45. Deng L, Krauss S, Feichtmayer J et al (2014) Grazing of heterotrophic flagellates on viruses is driven by feeding behaviour: grazing of flagellates on viruses. Environ Microbiol Rep 6:325-330. https://doi. org/10.1111/1758-2229.12119

46. ISO 19458 (2006) Water quality-sampling for microbiological analysis. International Organisation for Standardisation, Geneva

47. IKSR (2012) Niedrigwasserperioden 2011 im Rheineinzugsgebiet. Internationale Kommission zum Schutz des Rheins, Koblenz, Germany. ISBN 3-94199414-X978-3-941994-14-0. https://www.iksr.org/fileadmin/user_upload/DKDM/ Dokumente/Fachberichte/DE/rp_De_0198.pdf. Accessed 19 Aug 2019

48. Demuth N, Gerlach N, van der Heijden S, Johst M (2016) Starkregen und Hochwasser in Rheinland-Pfalz im Mai/Juni 2016. Landesamt für Umwelt Rheinland-Pfalz, Mainz, Germany. https://www.hochwasser-rlp.de/publikatio nen/bericht_starkregen_hochwasser_juni2016.pdf. Accessed 19 Aug 2019

49. ISO 9308-3 (1998) Water quality - detection and enumeration of Escherichia coli and coliform bacteria in surface and waste water-Part 3: Miniaturized method (most probable number) by inoculation in liquid medium. International Organization for Standardization, Geneva

50. ISO 7899-2 (2000) Water quality — detection and enumeration of intestinal enterococci-Part 2: membrane filtration method. International Organization for Standardization, Geneva

51. ISO 10705-2 (2000) Water quality — detection and enumeration of bacteriophages-Part 2: enumeration of somatic coliphages. International Organization for Standardization, Geneva

52. DEW (2007) Deutsche Einheitsverfahren zur Wasser-, Abwasser und Schlammuntersuchung, EN 1189, EN-ISO 26777, DIN 38405 D9-2, DIN 38406 E5. Wiley-VCH, Weinheim

53. R Core Team (2018) R: a language and environment for statistical computing. Foundation for statistical computing, Vienna, Austria. https://www.Rproject. org/. Accessed 14 Aug 2018

54. Vu VQ (2011) ggbiplot: A ggplot2 based biplot R package version 0.55. http:// github.com/vqv/ggbiplot. Accessed 17 Jan 2019

55. Oksanen J, Blanchet FG, Friendly M et al (2018) vegan: community ecology package. R package version 2.5-3. https://CRAN.Rproject.org/packa ge=vegan. Accessed 17 Jan 2019

56. Wickham H (2016) ggplot2: elegant graphics for data analysis. Springer, New York

57. Royston JP (1982) An extension of Shapiro and Wilk's W test for normality to large samples. J R Stat Soc Ser C Appl Stat 31:115-124

58. Breusch TS, Pagan AR (1979) A simple test for heteroscedasticity and random coefficient variation. Econom J Econom Soc 47:1287-1294

\section{Publisher's Note}

Springer Nature remains neutral with regard to jurisdictional claims in published maps and institutional affiliations. 